\title{
Profil Implementasi Model Pembelajaran webbed dalam Mata Pelajaran IPA Terpadu di Indonesia (2013-2021)
}

${ }^{*}$ Irda Sukmawati Dewi

Universitas Negeri Surabaya, Surabaya, Indonesia

\begin{tabular}{|c|c|}
\hline A) Check for updates open a access @ @ (i) & DOI: https://doi.org/10.53621/jippmas.v1i1.3 \\
\hline Informasi Artikel & \multirow{11}{*}{$\begin{array}{l}\text { ABSTRAK } \\
\text { Penelitian ini dilakukan untuk mendeskripsikan dan menganalisis } \\
\text { implementasi pembelajaran IPA Terpadu model webbed di Indonesia. Metode } \\
\text { penelitian ini menggunakan metode kualitatif dengan menggunakan data } \\
\text { sekunder. Sampel pada penelitian ini adalah artikel ilmiah yang telah } \\
\text { dipublikasikan di jurnal mahasiswa dan nasional sebanyak } 33 \text { artikel. } \\
\text { Berdasarkan analisis } 33 \text { artikel tentang pembelajaran IPA Terpadu model } \\
\text { webbed di Indonesia, dapat diketahui bahwa pembelajaran IPA Terpadu } \\
\text { model webbed di Indonesia berdampak positif terhadap hasil belajar peserta } \\
\text { didik, yang meliputi tercapainya ketuntasan hasil belajar peserta didik (aspek } \\
\text { kognitif, psikomotor, dan afektif), peserta didik lebih mudah memahami } \\
\text { materi IPA Terpadu, meningkatkan, peserta didik aktif berpartisipasi dalam } \\
\text { proses pembelajaran, meningkatkan penguasaan konsep peserta didik. }\end{array}$} \\
\hline Riwayat Artikel: & \\
\hline uni 2021 & \\
\hline Revisi Akhir: 29 Juni 2021 & \\
\hline 30 Juni 2021 & \\
\hline & \\
\hline $\begin{array}{l}\text { Kata Kunci: } \\
\text { IPA Terpadu }\end{array}$ & \\
\hline Implementasi & \\
\hline Model Webbed & \\
\hline Studi Litera & \\
\hline 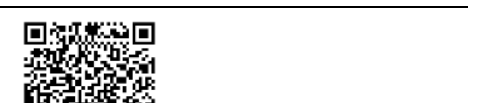 & \\
\hline
\end{tabular}

\section{PENDAHULUAN}

Tujuan Bangsa Indonesia tercantum dalam UUD 1945 pada alenia ke-empat, dimana salah satu tujuan bangsa Indonesia adalah "mencerdaskan kehidupan bangsa". Tujuan ini dapat dicapai saat masyarakat Indonesia mengerti akan pentingnya pendidikan, pendidikan adalah salah satu upaya dalam meningkatkan dan memajukan sumber daya manusia (SDM) (Priscylio \& Anwar, 2019).

Menurut (Sapari, Jatmiko \& Hidayat, 2015; Nuraida, Widiantle, Setiawati, 2019; Bahri, Sumaryanto, Haryono, 2020) pada penelitiannya mengungkapkan bahwa pendidikan adalah salah satu usaha dalam mengembangkan potensi diri untuk memiliki kemampuan spiritual keagamaan, kepribadian, pengendalian diri, akhlak mulia dan keterampilan dalam dirinya, lingkungan masyarakat, bangsa dan negara. Hingga saat ini banyak permasalah pendidikan yang harus dihadapi Negara Indonesia dalam memajukan sistem pendidikan. Salah satunya kurang optimalnya pembelajaran dalam kelas di Negara Indonesia (Nabila, Supartono, \& Nurhayati, 2017; Choiriyah, Madlazim \& Haryono, 2017; Nuraida, Widiantle \& Setiawati, 2019).

Pembelajaran adalah suatu alur dimana manusia secara sengaja diatur untuk turut serta dalam situasi tertentu untuk mendapatkan respon dari peserta didik. Dari penjelasan tersebut dapat disimpulkan bahwa kegiatan belajar berpusat pada peserta didik dan bukan berpusat pada kegiatan guru dalam mengelolah kelas (Utami, Darsana \& Suadyana, 2014). Kegiatan belajar mengajar di dalam kelas merupakan kegiatan interaksi yang dilakukan oleh guru dan peserta didik di sekolah. Namun dari beberapa kasus yang ada, kegiatan pembelajaran dalam kelas terasa membosankan dan menyebabkan melemahnya minat belajar peserta didik dalam kelas karena guru masih dominan (teacher center) dalam pembelajaran (Sapari, Jatmiko \& Hidayat, 2015). 
Profil Implementasi Model Pembelajaran webbed dalam Mata Pelajaran IPA Terpadu di Indonesia (20132021)

Selain guru yang masih dominan dalam proses pembelajaran dalam kelas, penyampaian informasi dan pengetahuan pada umumnya tanpa mengaitkan keterampilan pada proses pembelajaran. Sehingga pembelajaran hanya memberikan pengalaman artifisial atau pengalaman belajar simulasi. Pembelajaran harus dirancang dengan tepat karena dapat mempengaruhi kebermaknaan pengalaman belajar anak (Bahri, Sumaryanto \& Haryono, 2020).

Dari penjelasan oleh Moh. Syaeful dkk, dapat disimpulkan bahwa perlunya rancangan pembelajaran yang dapat meningkatkan kebermaknaan pengalaman belajar. Salah satu perangkat pembelajaran yang berisi rancangan pelajaran dan cara yang digunakan sebagai pendoman kegiatan belajar mengajar dalam waktu tertentu adalah kurikulum. Kurikulum yang ada di Negara Indonesia saat ini adalah kurikulum 2013. Berdasarkan kurikulum 2013 pada tingkat SMP (Sekolah Menengah Pertama) dikembangkan dengan konsep IPA terpadu atau Integrative Science. Menurut (Ridho, Haryani \& Habibah, 2014; Habibah \& Maryanto, 2019) pembelajaran IPA sebaiknya diajarkan secara terpadu dan tidak terpisah antara materi Fisika, Biologi, dan Kimia. Pembelajaran terpadu sepuluh model pembelajaran IPA terpadu dan tiga dari sepuluh model keterpaduan mudah dikembangkan dan dilaksanakan pada tingkat pembelajaran formal dalam kelas salah satunya adalah model terjaring (webbed). Model pembelajaran IPA terpadu tipe webbed adalah pembelajaran yang menggunakan kesepakatan dalam penentuan tema dalam diskusi oleh peserta didik dan guru. Setelah itu tema tersebut dikembangkan menjadi beberapa sub tema dan memperhatikan keterkaitan setiap bidang studi (Hilmawati \& Hidayat, 2013). Terdapat beberapa kelebihan model pembelajaran IPA terpadu tipe webbed yaitu 1) Penentuan tema disesuaikan minat peserta didik sehingga akan memotivasi peserta didik untuk belajar, 2) mudah dilakukan oleh pendidik yang belum berpengalaman, 3) memberikan kemudahan bagi peserta didik melihat kegiatankegiatan dan ide-ide berbeda yang terkait (Syamsudin, Ibrahim \& Widodo, 2016). Dari penjelasan diatas dapat diketahui bahwa model pembelajaran tipe webbed sangat direkomendasikan untuk diterapkan dalam pembelajaran formal. Sehingga dalam penelitian ini penulis akan mendeskripsikan implementasi pembelajaran webbed dalam Mata Pelajaran IPA terpadu di Indonesia pada 2012-2021.

\section{METODE PENELITIAN}

Penelitian diartikan sebagai suatu proses pengumpulan data dan analisis data yang dilakukan secara sistematis dan logis untuk mencapai tujuan tertentu (Mulyatiningsih, 2014). Pada penelitian ini menggunakan metode meta analisis dengan kajian literatur. Penelitian ini bersifat deskriptif kualitatif, metode ini diaplikasikan untuk menguraikan bagaimana implementasi model pembelajaran webbed dalam IPA Terpadu tingkat Sekolah Menengah Pertama (SMP) di Indonesia pada tahun 2012-2020. Pada penelitian ini, subjek penelitian adalah penulis sendiri, yang akan menganalisis penelitian sebelumnya yang berkaitan dengan implementasi model pembelajaran webbed dalam IPA Terpadu tingkat Sekolah Menengah Pertama (SMP) di Indonesia pada tahun 20122020.

Analisis data deskriptif kualitatif pada penelitian ini menggunakan analisis data sekunder, dimana dalam analisis data sekunder, kita menggunakan objek yang "tidak hidup", kita dapat memanfaatkan memanfaatkan majalah, koran, acara TV, buku-buku, syair lagu, cerita film sebagai objek penelitian (Martono, 2010). Uraian tersebut, penelitian ini menggunakan sumber data yang dari karya-karya ilmiah terdahulu yang 
berkaitan dengan pembahasan penelitian yang dianalisis kembali untuk memecahkan permasalahan yang diteliti dengan sumber data.

Pada penelitian ini menggunakan pendekatan penelitian Studi Kepustakaan (Library Research). Studi kepustakaan merupakan suatu studi yang digunakan dalam mengumpulkan informasi dan data dengan bantuan berbagai macam material yang ada di perpustakaan seperti dokumen, buku, majalah, kisah-kisah sejarah, dsb (Mirzaqon \& Purwoko, 2018). Dalam penelitian ini, dikumpulkan data dari penelitian yang relevan, yaitu tentang model pembelajaran nested-integrated dalam IPA Terpadu tingkat Sekolah Menengah Pertama (SMP) di Indonesia dari berbagai artikel yang mendukung permasalahan penelitian ini. Tujuan digunakannya metode studi kepustakaan ini adalah agar memperoleh pengetahuan baru yang kemudian dapat diterima dan dianalisis lebih dalam oleh peneliti untuk menjelaskan keberlangsugan model pembelajaran nestedintegrated dalam IPA Terpadu tingkat Sekolah Menengah Pertama (SMP) di Indonesia pada tahun 2012-2020 .

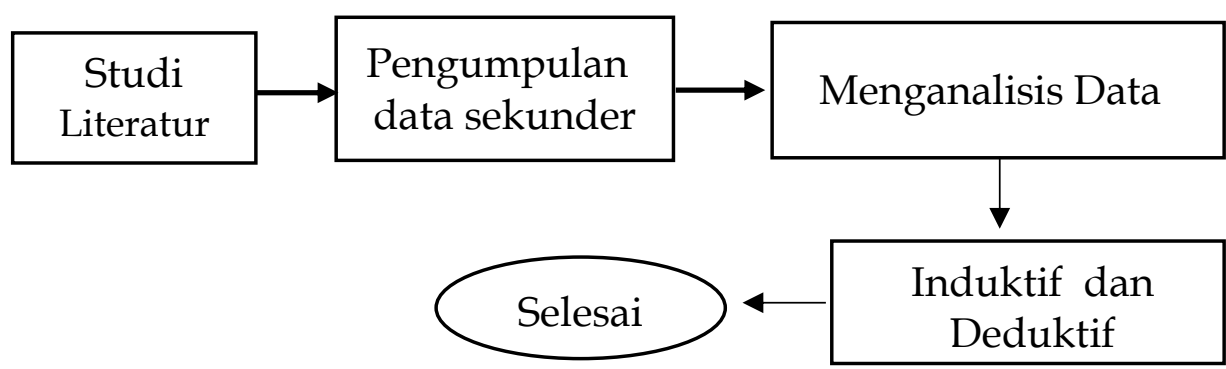

Gambar 1. Flowchart Penelitian profil implementasi model pembelajaran webbed dalam mata pelajaran IPA di Indonesia.

\section{HASIL DAN DISKUSI}

Table 1. Studi Literatur Implementasi Pembelajaran IPA Terpadu Model Webbed di Indonesia Tahun 2013-2021

\begin{tabular}{|c|c|c|c|}
\hline Penulis (Tahun) & $\begin{array}{c}\text { Karakteristik } \\
\text { Sampel }\end{array}$ & $\begin{array}{c}\text { Desain } \\
\text { Penelitian }\end{array}$ & Temuan \\
\hline $\begin{array}{l}\text { Hidayah, A., } \\
\text { N., Rahayu, Y., } \\
\text { S., \& Setiawan, } \\
\text { B. (2013) }\end{array}$ & $\begin{array}{l}\text { Subjek penelitian } \\
\text { adalah adalah } 15 \\
\text { peserta didik } \\
\text { kelas VIII SMP } \\
\text { Negeri } 1 \text { Kalitidu } \\
\text { Bojonegoro. }\end{array}$ & $\begin{array}{l}\text { - Jenis penelitian adalah } \\
\text { pengembangan } \\
\text { perangkat } \\
\text { pembelajaran IPA } \\
\text { terpadu tipe webbed } \\
\text { tema 4p. } \\
\text { - Menggunakan model } \\
\text { pembelajaran STAD. } \\
\text { - Rancangan penelitian } \\
\text { menggunakan design } \\
\text { pre-test and post-test } \\
\text { design. } \\
\text { - Metode penelitian } \\
\text { menggunakan reasearch } \\
\text { and development (RED). }\end{array}$ & $\begin{array}{l}\text { - Pelaksanaan } \\
\text { pembelajaran } \\
\text { mendapatkan kategori } \\
\text { sangat baik. } \\
\text { - Keterlaksanaan } \\
\text { memperoleh kriteria } \\
\text { sangat baik. } \\
\text { - Respon peserta didik baik } \\
\text { terhadap pembelajaran } \\
\text { yang dilakukan. } \\
\text { - Ketuntasan hasil belajar } \\
\text { mencapai } 86,67 \% \text {. }\end{array}$ \\
\hline
\end{tabular}


Profil Implementasi Model Pembelajaran webbed dalam Mata Pelajaran IPA Terpadu di Indonesia (20132021)

\begin{tabular}{|c|c|c|c|}
\hline $\begin{array}{l}\text { Santoso, A., } \\
\text { Purnomo, T., \& } \\
\text { Ismono. } \\
(2013)\end{array}$ & $\begin{array}{l}\text { Subjek penelitian } \\
\text { adalah } 15 \text { peserta } \\
\text { didik SMP Integral } \\
\text { Luqman Al-Hakim } \\
\text { Surabaya kelas } \\
\text { VIII-E pada } \\
\text { semester genap } \\
\text { tahun ajaran 2012- } \\
2013 \text {. }\end{array}$ & $\begin{array}{l}\text { - Jenis penelitian } \\
\text { pengembangan perangkat } \\
\text { pembelajaran Ipa } \\
\text { Terpadu tipe webbed. } \\
\text { - Penelitian menggunakan } \\
\text { model 4-D (define, design, } \\
\text { develop dan disseminate). } \\
\text { - Hasil penelitian dianalisis } \\
\text { menggunakan metode } \\
\text { deskriptif kualitatif. }\end{array}$ & $\begin{array}{l}\text { - Perangkat pembelajaran IPA } \\
\text { terpadu tipe webbed pada } \\
\text { tema pestisida untuk } \\
\text { melatih karakter peserta } \\
\text { didik SMP sangat layak } \\
\text { digunakan. }\end{array}$ \\
\hline $\begin{array}{l}\text { Af'idah, A., R., } \\
\text { Erman, \& } \\
\text { Budiyanto, M. } \\
\text { (2013) }\end{array}$ & $\begin{array}{l}\text { Subjek penelitian } \\
\text { adalah } 14 \text { peserta } \\
\text { didik SMP } \\
\text { Negeri } 1 \text { Bungah } \\
\text { kelas VII-A tahun } \\
\text { ajaran 2012-2013. }\end{array}$ & $\begin{array}{l}\text { - Jenis penelitian adalah } \\
\text { penelitian deskriptif. } \\
\text { - Rancangan penelitian } \\
\text { menggunakan one shot } \\
\text { case study. }\end{array}$ & $\begin{array}{l}\text { - Pelaksanaan } \\
\text { pembelajaran } \\
\text { berdasarkan masalah IPA } \\
\text { terpadu tipe webbed } \\
\text { dengan tema korosi } \\
\text { terlaksana } 100 \% \text {. } \\
\text { - Aktivitas peserta didik } \\
\text { pada ranah kognitif } \\
\text { masuk kategori baik. } \\
\text { Pada ranah psikomotor } \\
\text { dan afektif masuk dalam } \\
\text { kategori sangat baik. } \\
\text { - Respon peserta didik } \\
\text { sangat baik. }\end{array}$ \\
\hline $\begin{array}{l}\text { Rachmadani, D., } \\
\text { \& Supardi, Z., } \\
\text { A., I. } \\
\text { (2013) }\end{array}$ & $\begin{array}{l}\text { Subjek penelitian } \\
\text { adalah } 39 \text { peserta } \\
\text { didik SMP Negeri } \\
\text { 19 Surabaya kelas } \\
\text { VIII-D tahun ajaran } \\
\text { 2012-2013. }\end{array}$ & $\begin{array}{l}\text { - Jenis penelitian } \\
\text { pengembangan perangkat } \\
\text { pembelajaran Ipa } \\
\text { Terpadu tipe webbed. } \\
\text { - Penelitian menggunakan } \\
\text { model 4-D (define, design, } \\
\text { develop dan disseminate). } \\
\text { - Hasil penelitian dianalisis } \\
\text { menggunakan metode } \\
\text { deskriptif kuantitatif. }\end{array}$ & $\begin{array}{l}\text { - Perangkat pembelajaran } \\
\text { IPA terpadu tipe webbed } \\
\text { pada tema tekanan darah } \\
\text { layak digunakan. } \\
\text { - Hasil belajar peserta didik } \\
\text { diperoleh nilai dan } \\
\text { ketuntasan klasikal } \\
\text { sangat baik. } \\
\text { - Respon peserta didik } \\
\text { positif terhadap } \\
\text { perangkat pembelajaran } \\
\text { yang dikembangkan. }\end{array}$ \\
\hline $\begin{array}{l}\text { Sari, D., P., } \\
\text { Mitarlis., \& } \\
\text { Rosdiana, L. } \\
\text { (2013) }\end{array}$ & $\begin{array}{l}\text { Subjek penelitian } \\
\text { ini adalah } 32 \\
\text { peserta didik kelas } \\
\text { VII A di SMPN } 1 \\
\text { Manyar Gresik }\end{array}$ & $\begin{array}{l}\text { - Penelitian penerapan } \\
\text { pembelajaran IPA } \\
\text { terpadu tipe webbed } \\
\text { dengan model } \\
\text { pembelajaran } \\
\text { berdasarkan masalah. } \\
\text { - Jenis penelitian adalah } \\
\text { pra-eksperimental } \\
\text { - Rancangan penelitian } \\
\text { menggunakan one shot } \\
\text { case study. } \\
\text { - Hasil penelitian dianalisis } \\
\text { menggunakan metode } \\
\text { deskriptif kuantitatif. }\end{array}$ & $\begin{array}{l}\text { - Pelaksanaan } \\
\text { pembelajaran IPA } \\
\text { terpadu tipe webbed } \\
\text { dengan model } \\
\text { pembelajaran } \\
\text { berdasarkan masalah } \\
\text { terlaksana } 100 \% . \\
\text { - Aktivitas peserta didik } \\
\text { pada ranah psikomotor } \\
\text { masuk dalam kategori } \\
\text { sangat baik. }\end{array}$ \\
\hline
\end{tabular}


Profil Implementasi Model Pembelajaran webbed dalam Mata Pelajaran IPA Terpadu di Indonesia (20132021)

\begin{tabular}{|c|c|c|c|}
\hline $\begin{array}{l}\text { Kartika, F., \& } \\
\text { Azizah, U. } \\
(2013)\end{array}$ & $\begin{array}{l}\text { Subjek penelitian } \\
\text { adalah } 12 \text { peserta } \\
\text { didik SMP } \\
\text { Negeri } 2 \\
\text { Pungging kelas } \\
\text { IX tahun ajaran } \\
\text { 2012-2013. }\end{array}$ & $\begin{array}{l}\text { - Jenis penelitian } \\
\text { pengembangan } \\
\text { perangkat } \\
\text { pembelajaran Ipa } \\
\text { Terpadu tipe webbed. } \\
\text { - Penelitian } \\
\text { menggunakan model } \\
\text { 4-D define, design, } \\
\text { develop dan disseminate). } \\
\text { - Hasil penelitian dianalisis } \\
\text { menggunakan metode } \\
\text { deskriptif kuantitatif. }\end{array}$ & $\begin{array}{l}\text { - Perangkat pembelajaran } \\
\text { IPA terpadu tipe webbed } \\
\text { pada tema bioteknologi } \\
\text { layak digunakan. } \\
\text { - Respon peserta didik } \\
\text { positif terhadap } \\
\text { perangkat pembelajaran } \\
\text { yang dikembangkan. }\end{array}$ \\
\hline $\begin{array}{l}\text { Sari, F., I., \& } \\
\text { Mulyaningsih, } \\
\text { S. } \\
(2013)\end{array}$ & $\begin{array}{l}\text { Subjek penelitian } \\
\text { adalah } 39 \text { peserta } \\
\text { didik SMP } \\
\text { Negeri } 19 \\
\text { Surabaya kelas } \\
\text { VIII-B tahun } \\
\text { ajaran 2012-2013. }\end{array}$ & $\begin{array}{l}\text { - Jenis penelitian adalah } \\
\text { pre-experimental design } \\
\text { dalam IPA terpadu tipe } \\
\text { webbed. } \\
\text { - Menggunakan model } \\
\text { pembelajaran STAD. } \\
\text { - Rancangan penelitian } \\
\text { menggunakan design } \\
\text { pre-test and post-test } \\
\text { design. } \\
\text { - Metode penelitian } \\
\text { menggunakan analisis } \\
\text { deskriptif kuantitatif. }\end{array}$ & $\begin{array}{l}\text { - Pelaksanaan } \\
\text { pembelajaran } \\
\text { mendapatkan kategori } \\
\text { baik dengan skor } 3,5 \text {. } \\
\text { - Respon peserta didik baik } \\
\text { terhadap pembelajaran } \\
\text { yang dilakukan. } \\
\text { - Ketuntasan hasil belajar } \\
\text { mencapai } 87,17 \% \text {. }\end{array}$ \\
\hline $\begin{array}{l}\text { Zakiyah, I., } \\
\text { Mulyaningsih, } \\
\text { S., \& Setiawan } \\
\text { B. } \\
(2013)\end{array}$ & $\begin{array}{l}\text { Subjek penelitian } \\
\text { adalah } 32 \text { peserta } \\
\text { didik SMP } \\
\text { Negeri } 1 \text { Bungah } \\
\text { Gresik kelas VII- } \\
\text { A. }\end{array}$ & $\begin{array}{l}\text { - Jenis penelitian adalah } \\
\text { pre-experimental design } \\
\text { atau quasi experiment. } \\
\text { - Rancangan penelitian } \\
\text { menggunakan design } \\
\text { pre-test and post-test } \\
\text { design. } \\
\text { - Metode penelitian } \\
\text { menggunakan analisis } \\
\text { deskriptif kuantitatif. }\end{array}$ & $\begin{array}{l}\text { - Pelaksanaan } \\
\text { pembelajaran IPA } \\
\text { Terpadu tipe webbed } \\
\text { sangat baik. } \\
\text { - Kinerja peserta didik } \\
\text { masuk dalam kategori } \\
\text { sangat baik. } \\
\text { - Ketuntasan hasil belajar } \\
\text { peserta didik mengalami } \\
\text { peningkatan. } \\
\text { - Respon peserta didik } \\
\text { positif terhadap } \\
\text { penerapan pembelajaran. } \\
\text { - Keterampilan berpikir } \\
\text { kritis peserta didik } \\
\text { meningkat. }\end{array}$ \\
\hline $\begin{array}{l}\text { Lutviyah, I., \& } \\
\text { Mulyaningsih, S. } \\
\text { (2013) }\end{array}$ & $\begin{array}{l}\text { Subjek penelitian } \\
\text { adalah } 38 \text { peserta } \\
\text { didik SMP Negeri } \\
1 \text { Jabon kelas VII- } \\
\text { A. }\end{array}$ & $\begin{array}{l}\text { - Jenis penelitian adalah } \\
\text { quasi experiment. } \\
\text { - Rancangan penelitian } \\
\text { menggunakan design pre- } \\
\text { test and post-test design. } \\
\text { - Metode penelitian } \\
\text { menggunakan analisis } \\
\text { deskriptif kuantitatif. }\end{array}$ & $\begin{array}{l}\text { - Pelaksanaan pembelajaran } \\
\text { IPA Terpadu tipe webbed } \\
\text { sangat baik. } \\
\text { - Hasil belajar peserta didik } \\
\text { meningkat dari aspek } \\
\text { kognitif, afektif dan } \\
\text { psikomotor. } \\
\text { - Respon peserta didik positif } \\
\text { terhadap penerapan } \\
\text { pembelajaran. }\end{array}$ \\
\hline
\end{tabular}


Profil Implementasi Model Pembelajaran webbed dalam Mata Pelajaran IPA Terpadu di Indonesia (20132021)

\begin{tabular}{|c|c|c|c|}
\hline $\begin{array}{l}\text { Putri, K., E., } \\
\text { Ismono, \& } \\
\text { Rosdiana, L. } \\
\text { (2013) }\end{array}$ & $\begin{array}{l}\text { Subjek penelitian } \\
\text { adalah } 16 \text { peserta } \\
\text { didik SMP } \\
\text { Negeri } 28 \\
\text { Surabaya kelas } \\
\text { VIII. }\end{array}$ & $\begin{array}{l}\text { - Jenis penelitian } \\
\text { pengembangan } \\
\text { perangkat } \\
\text { pembelajaran Ipa } \\
\text { Terpadu tipe webbed. } \\
\text { - Penelitian } \\
\text { menggunakan model } \\
\text { 4-D define, design, } \\
\text { develop dan disseminate). } \\
\text { - Hasil penelitian } \\
\text { dianalisis } \\
\text { menggunakan metode } \\
\text { deskriptif kuantitatif. }\end{array}$ & $\begin{array}{l}\text { - Perangkat pembelajaran } \\
\text { IPA terpadu tipe webbed } \\
\text { pada tema pemanasan } \\
\text { global layak digunakan. } \\
\text { - Hasil belajar peserta didik } \\
\text { diperoleh nilai dan } \\
\text { ketuntasan klasikal } \\
\text { sangat baik. } \\
\text { - Respon peserta didik } \\
\text { positif terhadap } \\
\text { perangkat pembelajaran } \\
\text { yang dikembangkan. }\end{array}$ \\
\hline $\begin{array}{l}\text { Maulidy, S., K., } \\
\text { \& Winarsih. } \\
(2013)\end{array}$ & $\begin{array}{l}\text { Subjek penelitian } \\
\text { adalah } 16 \text { peserta } \\
\text { didik SMP } \\
\text { Negeri } 1 \text { Labang } \\
\text { kelas VII-F. }\end{array}$ & $\begin{array}{l}\text { - Jenis penelitian adalah } \\
\text { pre-experiment design. } \\
\text { - Rancangan penelitian } \\
\text { menggunakan design } \\
\text { shot case study design. } \\
\text { - Instrument tes pre-test } \\
\text { and post-test design. } \\
\text { - Model Pembelajaran } \\
\text { yang digunakan STAD. }\end{array}$ & $\begin{array}{l}\text { - Respon peserta didik positif } \\
\text { terhadap penerapan } \\
\text { pembelajaran. }\end{array}$ \\
\hline $\begin{array}{l}\text { Nazila, M., R., } \\
\text { A., \& } \\
\text { Suliyanah. } \\
\text { (2013) }\end{array}$ & $\begin{array}{l}\text { Subjek penelitian } \\
\text { adalah } 26 \text { peserta } \\
\text { didik SMP } \\
\text { Negeri } 2 \\
\text { Jombang kelas } \\
\text { VIII-G. }\end{array}$ & $\begin{array}{l}\text { - Jenis penelitian adalah } \\
\text { pre-experimental design } \\
\text { atau quasi experiment. } \\
\text { - Rancangan penelitian } \\
\text { menggunakan design } \\
\text { pre-test and post-test } \\
\text { group design. } \\
\text { - Metode penelitian } \\
\text { menggunakan analisis } \\
\text { deskriptif kuantitatif. }\end{array}$ & $\begin{array}{l}\text { - Pelaksanaan pembelajaran } \\
\text { langsung pada IPA terpadu } \\
\text { tipe webbed sangat baik.. } \\
\text { - Peserta didik dinyatakan } \\
\text { tuntas dalam pembelajaran } \\
\text { baik secara klasikal maupun } \\
\text { individu. } \\
\text { - Respon peserta didik positif. } \\
\text { - Penerapan pembelajaran } \\
\text { langsung pada IPA terpadu } \\
\text { tipe webbed dapat } \\
\text { memberikan pengaruh } \\
\text { positif dalam aspek kognitif. }\end{array}$ \\
\hline $\begin{array}{l}\text { Hilmawati, N., \& } \\
\text { Hidayat, M., T. } \\
\text { (2013). }\end{array}$ & $\begin{array}{l}\text { Subjek penelitian } \\
\text { adalah } 15 \text { peserta } \\
\text { didik SMP Negeri } \\
\text { 1 Sidayu Gresik } \\
\text { kelas VII-F. }\end{array}$ & $\begin{array}{l}\text { - Jenis penelitian } \\
\text { pengembangan perangkat } \\
\text { pembelajaran Ipa } \\
\text { Terpadu tipe webbed. } \\
\text { - Penelitian menggunakan } \\
\text { model 4-D define, design, } \\
\text { develop dan disseminate). } \\
\text { - Hasil penelitian dianalisis } \\
\text { menggunakan metode } \\
\text { deskriptif kuantitatif. }\end{array}$ & $\begin{array}{l}\text { - Perangkat pembelajaran IPA } \\
\text { terpadu tipe webbed } \\
\text { berbasis contextual teaching } \\
\text { and learning layak } \\
\text { digunakan. } \\
\text { - Hasil belajar peserta didik } \\
\text { diperoleh nilai dan } \\
\text { ketuntasan klasikal sangat } \\
\text { baik. } \\
\text { - Respon peserta didik positif } \\
\text { terhadap perangkat } \\
\text { pembelajaran yang } \\
\text { dikembangkan. } \\
\text { - Pengembangan perangkat } \\
\text { pembelajaran dapat } \\
\text { meningkatkan aktivitas } \\
\text { konstruktivisme peserta } \\
\text { didik. }\end{array}$ \\
\hline
\end{tabular}




\begin{tabular}{|c|c|c|c|}
\hline $\begin{array}{l}\text { Ahmadi, N., } \\
\text { Purnomo, T., \& } \\
\text { Martini. } \\
\text { (2013). }\end{array}$ & $\begin{array}{l}\text { Subjek penelitian } \\
\text { adalah } 20 \text { peserta } \\
\text { didik MTs Al- } \\
\text { Hidayah Kendal, } \\
\text { Ngawi kelas VII- } \\
\text { A. }\end{array}$ & $\begin{array}{l}\text { - Jenis penelitian } \\
\text { pengembangan } \\
\text { perangkat } \\
\text { pembelajaran Ipa } \\
\text { Terpadu tipe webbed. } \\
\text { - Penelitian } \\
\text { menggunakan model } \\
\text { 4-D define, design, } \\
\text { develop dan disseminate). } \\
\text { - Hasil penelitian } \\
\text { dianalisis } \\
\text { menggunakan metode } \\
\text { deskriptif kuantitatif. }\end{array}$ & $\begin{array}{l}\text { - Perangkat pembelajaran } \\
\text { IPA terpadu tipe webbed } \\
\text { pada tema pencemaran } \\
\text { air berorientasi model } \\
\text { Problem Based Intruction } \\
\text { (PBI) layak digunakan. } \\
\text { - Hasil belajar peserta didik } \\
\text { meningkat. } \\
\text { - Ketuntasan belajar } \\
\text { peserta didik mencapai } \\
84,2 \% \text {. } \\
\text { - Respon peserta didik } \\
\text { positif terhadap } \\
\text { perangkat pembelajaran } \\
\text { yang dikembangkan. }\end{array}$ \\
\hline $\begin{array}{l}\text { Aini, N., } \\
\text { Tukiran, \& } \\
\text { Qosyim, A. } \\
\text { (2013). }\end{array}$ & $\begin{array}{l}\text { Subjek penelitian } \\
\text { adalah } 31 \text { peserta } \\
\text { didik SMP } \\
\text { Negeri } 1 \text { Madiun } \\
\text { kelas VIII-F. }\end{array}$ & $\begin{array}{l}\text { - Jenis penelitian adalah } \\
\text { pre-experimental design } \\
\text { dalam IPA terpadu tipe } \\
\text { webbed. } \\
\text { - Menggunakan model } \\
\text { pembelajaran guided } \\
\text { discovery. } \\
\text { - Rancangan penelitian } \\
\text { menggunakan design } \\
\text { one shot case study. } \\
\text { - Metode penelitian } \\
\text { menggunakan analisis } \\
\text { deskriptif kuantitatif. }\end{array}$ & $\begin{array}{l}\text { - Pelaksanaan } \\
\text { pembelajaran model } \\
\text { penemuan terbimbing } \\
\text { pada ipa terpadu tipe } \\
\text { webbed dengan tema } \\
\text { biopestisida } \\
\text { mendapatkan kategori } \\
\text { sangat baik. } \\
\text { - Respon peserta didik } \\
\text { positif terhadap } \\
\text { pembelajaran yang } \\
\text { dilakukan. } \\
\text { - Ketuntasan hasil belajar } \\
\text { mencapai } 87 \% \text {. }\end{array}$ \\
\hline $\begin{array}{l}\text { Rahmatika, R., } \\
\text { Ismono, \& } \\
\text { Budiyanto, M. } \\
\text { (2013). }\end{array}$ & $\begin{array}{l}\text { Subjek penelitian } \\
\text { adalah } 12 \text { peserta } \\
\text { didik MTs Negeri } \\
2 \text { Kediri VIII-D. }\end{array}$ & $\begin{array}{l}\text { - Jenis penelitian } \\
\text { pengembangan } \\
\text { perangkat } \\
\text { pembelajaran Ipa } \\
\text { Terpadu tipe webbed. } \\
\text { - Penelitian } \\
\text { menggunakan model } \\
\text { 4-D define, design, } \\
\text { develop dan disseminate). } \\
\text { - Hasil penelitian } \\
\text { dianalisis } \\
\text { menggunakan metode } \\
\text { deskriptif kuantitatif. }\end{array}$ & $\begin{array}{l}\text { - Perangkat pembelajaran } \\
\text { IPA terpadu tipe webbed } \\
\text { pada tema pengolahan } \\
\text { minyak kelapa memenuhi } \\
\text { aspek kelayakan, } \\
\text { kepraktisan dan } \\
\text { keefektifan. }\end{array}$ \\
\hline $\begin{array}{l}\text { Tanjung, R., \& } \\
\text { Kamal, R. (2013) }\end{array}$ & $\begin{array}{l}\text { Subjek penelitian } \\
\text { adalah peserta } \\
\text { didik SMP Swasta } \\
\text { IKAL Medan kelas } \\
\text { VIII. }\end{array}$ & $\begin{array}{l}\text { - Menggunakan model } \\
\text { pembelajaran IPA } \\
\text { terpadu tipe webbed. } \\
\text { - Design penelitian two } \\
\text { group pretest postest. } \\
\text { - Metode penelitian } \\
\text { menggunakan analisis } \\
\text { deskriptif kuantitatif. }\end{array}$ & $\begin{array}{l}\text { - Model Pembelajaran Ipa } \\
\text { terpadu tipe webbed dapat } \\
\text { meningkatkan hasil } \\
\text { belajar peserta didik kelas } \\
\text { VII SMP Swasta IKAL } \\
\text { Medan. }\end{array}$ \\
\hline
\end{tabular}


Profil Implementasi Model Pembelajaran webbed dalam Mata Pelajaran IPA Terpadu di Indonesia (20132021)

\begin{tabular}{|c|c|c|c|}
\hline $\begin{array}{l}\text { Yulianingrum, } \\
\text { \& Rahayu, y., S } \\
\text { (2013) }\end{array}$ & $\begin{array}{l}\text { Subjek penelitian } \\
\text { adalah } 23 \text { peserta } \\
\text { didik SMP Al- } \\
\text { Amal kelas VIII- } \\
\text { A. }\end{array}$ & $\begin{array}{l}\text { - Jenis penelitian adalah } \\
\text { deskriptif. } \\
\text { - Rancangan penelitian } \\
\text { menggunakan design } \\
\text { pre-test and post-test } \\
\text { group design. } \\
\text { - Metode penelitian } \\
\text { menggunakan analisis } \\
\text { deskriptif kuantitatif. }\end{array}$ & $\begin{array}{l}\text { - Pelaksanaan } \\
\text { pembelajaran langsung } \\
\text { pada IPA terpadu tipe } \\
\text { webbed berorientasi pada } \\
\text { life skill dilakukan dengan } \\
\text { kriteria sangat baik. } \\
\text { - Kecakapan berpikir } \\
\text { rasional dan akademik } \\
\text { mengalami peningkatan. } \\
\text { - Peserta didik dinyatakan } \\
\text { tuntas dalam } \\
\text { pembelajaran baik secara } \\
\text { klasikal maupun individu } \\
\text { dan mengalami } \\
\text { peningkatan hasil belajar. } \\
\text { - Respon peserta didik } \\
\text { positif. }\end{array}$ \\
\hline $\begin{array}{l}\text { Heru \& } \\
\text { Mulyaningsih., } \\
\text { S. } \\
(2014)\end{array}$ & $\begin{array}{l}\text { Subjek penelitian } \\
\text { adalah } 16 \text { peserta } \\
\text { didik SMP } \\
\text { Negeri } 1 \text { Dlanggu } \\
\text { Mojokerto kelas } \\
\text { VII. }\end{array}$ & $\begin{array}{l}\text { - Jenis penelitian adalah } \\
\text { pre-experimental design } \\
\text { dalam IPA terpadu tipe } \\
\text { webbed. } \\
\text { - Menggunakan model } \\
\text { pembelajaran STAD. } \\
\text { - Rancangan penelitian } \\
\text { menggunakan design } \\
\text { pre-test and post-test } \\
\text { design. } \\
\text { - Metode penelitian } \\
\text { menggunakan analisis } \\
\text { deskriptif kuantitatif. }\end{array}$ & $\begin{array}{l}\text { - Pelaksanaan pembelajaran } \\
\text { IPA terpadu tipe webbed } \\
\text { menggunakan model } \\
\text { kooperatif STAD pada tema } \\
\text { roket air mendapatkan } \\
\text { kategori baik. } \\
\text { - Hasil belajar peserta didik } \\
\text { mengalami peningkatan. } \\
\text { - Peserta didik mengalami } \\
\text { ketuntasan pada aspek } \\
\text { kognitif, afektif dan } \\
\text { psikomotor. }\end{array}$ \\
\hline $\begin{array}{l}\text { Amarila, R., S., } \\
\text { Habibah, N., A., } \\
\text { \& Widiyatmoko, } \\
\text { A. } \\
(2014)\end{array}$ & $\begin{array}{l}\text { Subjek penelitian } \\
\text { adalah pakar, guru } \\
\text { IPA dan peserta } \\
\text { didik kelas VII di } \\
\text { SMP Negeri } 1 \\
\text { Bangsri Jepara }\end{array}$ & $\begin{array}{l}\text { - Jenis penelitian adalah } \\
\text { pengembangan alat } \\
\text { evaluasi. } \\
\text { - Metode penelitian adalah } \\
\text { penelitian dan } \\
\text { pengembangan }(R \mathcal{E} D) \text {. } \\
\text { - Metode penelitian } \\
\text { menggunakan analisis } \\
\text { deskriptif kuantitatif. }\end{array}$ & $\begin{array}{l}\text { - Alat Evaluasi sangat layak } \\
\text { dikembangkan. } \\
\text { - Alat Evaluasi pembelajaran } \\
\text { IPA terpadu model webbed } \\
\text { tema lingkungan mampu } \\
\text { mengukur kemampuan } \\
\text { berpikir kritis peserta didik. }\end{array}$ \\
\hline $\begin{array}{l}\text { Ridho, S., } \\
\text { Haryani, S., } \\
\text { Habibah, N., A. } \\
\text { (2014) }\end{array}$ & $\begin{array}{l}\text { Subjek penelitian } \\
\text { adalah pakar, } \\
\text { guru IPA dan } \\
\text { peserta didik } \\
\text { kelas VIII di SMP } \\
\text { Negeri } 2 \text { Subah } \\
\text { Batang. }\end{array}$ & $\begin{array}{l}\text { - Jenis penelitian adalah } \\
\text { pengembangan modul } \\
\text { IPA terpadu tipe } \\
\text { webbed pada tema hama } \\
\text { dan pestisida. } \\
\text { - Metode penelitian } \\
\text { adalah penelitian dan } \\
\text { pengembangan }(R \mathcal{E} D) \text {. } \\
\text { - Metode penelitian } \\
\text { menggunakan analisis } \\
\text { deskriptif kuantitatif. }\end{array}$ & $\begin{array}{l}\text { - Modul IPA terpadu tipe } \\
\text { webbed pada tema hama } \\
\text { dan pestisida sangat } \\
\text { layak dikembangkan. }\end{array}$ \\
\hline
\end{tabular}


Profil Implementasi Model Pembelajaran webbed dalam Mata Pelajaran IPA Terpadu di Indonesia (20132021)

\begin{tabular}{|c|c|c|c|}
\hline $\begin{array}{l}\text { Bariroh, S., L, } \\
\text { Muchlis \& } \\
\text { Fauziah, N., M. } \\
\text { (2014) }\end{array}$ & $\begin{array}{l}\text { Subjek penelitian } \\
\text { adalah } 12 \text { peserta } \\
\text { didik kelas VIII-I } \\
\text { di MTs Ngrogot } \\
\text { Nganjuk. }\end{array}$ & $\begin{array}{l}\text { - Jenis penelitian } \\
\text { pengembangan } \\
\text { perangkat } \\
\text { pembelajaran Ipa } \\
\text { Terpadu tipe webbed. } \\
\text { - Penelitian } \\
\text { menggunakan model } \\
\text { 4-D define, design, } \\
\text { develop dan disseminate). } \\
\text { - Hasil penelitian } \\
\text { dianalisis } \\
\text { menggunakan metode } \\
\text { deskriptif kuantitatif. }\end{array}$ & $\begin{array}{l}\text { - Lembar Kerja Siswa (LKS) } \\
\text { IPA Terpadu Berbasis } \\
\text { Pembelajaran } \\
\text { Berdasarkan Masalah } \\
\text { Tema Polusi Cahaya } \\
\text { layak digunakan. } \\
\text { - Hasil belajar peserta didik } \\
\text { meningkat. } \\
\text { - Respon peserta didik } \\
\text { positif terhadap } \\
\text { perangkat pembelajaran } \\
\text { yang dikembangkan. }\end{array}$ \\
\hline $\begin{array}{l}\text { Mansurotun, S., } \\
\text { Astriani, D., \& } \\
\text { Sanjaya, I., G., } \\
\text { M.. } \\
\text { (2014) }\end{array}$ & $\begin{array}{l}\text { Subjek penelitian } \\
\text { adalah } 25 \text { peserta } \\
\text { didik MTs Al- } \\
\text { Hidayah kelas } \\
\text { VIII-A. }\end{array}$ & $\begin{array}{l}\text { - Jenis penelitian } \\
\text { pengembangan } \\
\text { perangkat } \\
\text { pembelajaran Ipa } \\
\text { Terpadu tipe webbed. } \\
\text { - Penelitian } \\
\text { menggunakan model } \\
\text { 4-D (define, design, } \\
\text { develop dan disseminate). } \\
\text { - Hasil penelitian } \\
\text { dianalisis } \\
\text { menggunakan metode } \\
\text { deskriptif kuantitatif. }\end{array}$ & $\begin{array}{l}\text { - Perangkat pembelajaran } \\
\text { IPA terpadu tipe webbed } \\
\text { berorientasi inkuiri } \\
\text { terbimbing rainbow cake } \\
\text { sangat layak digunakan } \\
\text { dengan skor } 84,9 \% \text {. } \\
\text { - Kegiatan pembelajaran } \\
\text { terlaksana dengan baik. } \\
\text { - Hasil belajar peserta didik } \\
\text { mencapai ketuntasan } \\
\text { mencapai } 100 \% \text {. } \\
\text { - Peserta didik } \\
\text { memberikan respon } \\
\text { positif. }\end{array}$ \\
\hline $\begin{array}{l}\text { Syamsudin, } \\
\text { Ibrahim, M., \& } \\
\text { Widodo, W. } \\
(2016)\end{array}$ & $\begin{array}{l}\text { Subjek penelitian } \\
\text { adalah } 32 \text { peserta } \\
\text { didik kelas VIII di } \\
\text { MTs Al-Fitrah } \\
\text { Surabaya }\end{array}$ & $\begin{array}{l}\text { - Jenis penelitian } \\
\text { pengembangan perangkat } \\
\text { pembelajaran Ipa } \\
\text { Terpadu tipe webbed. } \\
\text { - Penelitian menggunakan } \\
\text { model 4-D define, design, } \\
\text { develop dan disseminate). } \\
\text { - Hasil penelitian dianalisis } \\
\text { menggunakan metode } \\
\text { deskriptif kuantitatif- } \\
\text { kualitatif. }\end{array}$ & $\begin{array}{l}\text { - Perangkat pembelajaran IPA } \\
\text { terpadu tipe webbed berbasis } \\
\text { inkuiri terbimbing layak } \\
\text { digunakan ditinjau dari } \\
\text { aspek kevalidan, praktis dan } \\
\text { efektif. } \\
\text { - Perangkat pembelajaran } \\
\text { mampu melatih } \\
\text { kemandirian dan kecakapan } \\
\text { peserta didik SMP. }\end{array}$ \\
\hline $\begin{array}{l}\text { Zuraida, I., } \\
\text { Kariadinata, R., } \\
\text { \& Susilawati, } \\
\text { W. } \\
\text { (2015) }\end{array}$ & $\begin{array}{l}\text { Subjek penelitian } \\
\text { adalah kelas VII } \\
\text { di salah satu SMP } \\
\text { di Kota Bandung. }\end{array}$ & $\begin{array}{l}\text { - Jenis penelitian adalah } \\
\text { quasi experiment dengan } \\
\text { Matching Pretest- } \\
\text { Posttest Control Group } \\
\text { Design. }\end{array}$ & $\begin{array}{l}\text { - Terdapat perbedaan } \\
\text { kemampuan dan } \\
\text { peningkatan kemampuan } \\
\text { berpikir kreatif siswa } \\
\text { antara yang memperoleh } \\
\text { pembelajaran } \\
\text { pembelajaran Mind Map } \\
\text { Siklus, Mind Map Laba- } \\
\text { laba dan Konvensional } \\
\text { pada pokok bahasan } \\
\text { bangun ruang. }\end{array}$ \\
\hline
\end{tabular}


Profil Implementasi Model Pembelajaran webbed dalam Mata Pelajaran IPA Terpadu di Indonesia (20132021)

\begin{tabular}{|c|c|c|c|}
\hline $\begin{array}{l}\text { Suryaneza, H., } \\
\text { \& Permanasari, } \\
\text { A. } \\
(2016)\end{array}$ & $\begin{array}{l}\text { Subjek penelitian } \\
\text { adalah adalah } 34 \\
\text { peserta didik } \\
\text { SMP Negeri } 1 \\
\text { Tengah Tani, }\end{array}$ & $\begin{array}{l}\text { - Jenis penelitian adalah } \\
\text { quasi experiment. } \\
\text { - Rancangan penelitian } \\
\text { menggunakan design } \\
\text { design non-randomized } \\
\text { subject pretest posttest } \\
\text { control-group. }\end{array}$ & $\begin{array}{l}\text { - Literasi sains peserta } \\
\text { didik mengalami } \\
\text { peningkatan setelah } \\
\text { diterapkan pembelajaran } \\
\text { IPA terpadu model } \\
\text { webbed. }\end{array}$ \\
\hline $\begin{array}{l}\text { Sukarisih, L. } \\
\text { (2017) }\end{array}$ & $\begin{array}{l}\text { Subjek penelitian } \\
\text { adalah } 12 \text { peserta } \\
\text { didik SMP } \\
\text { Negeri } 10 \text { Kota } \\
\text { Kendari kelas } \\
\text { VIII. }\end{array}$ & $\begin{array}{l}\text { - Jenis penelitian } \\
\text { adalapengembangan } \\
\text { bahan ajar } \\
\text { pembelajaran Ipa } \\
\text { Terpadu tipe webbed. } \\
\text { - Penelitian } \\
\text { menggunakan model } \\
\text { 4-D define, design, } \\
\text { develop dan disseminate). } \\
\text { - Hasil penelitian } \\
\text { dianalisis } \\
\text { menggunakan metode } \\
\text { deskriptif kuantitatif. }\end{array}$ & $\begin{array}{l}\text { - Bahan ajar yang } \\
\text { dikembangkan pada } \\
\text { pembelajaran IPA } \\
\text { terpadu tipe integred } \\
\text { webbed dengan analisis } \\
\text { wacana pada } \\
\text { pembelajaran fisika layak } \\
\text { digunakan. }\end{array}$ \\
\hline $\begin{array}{l}\text { Margaretta, Y., } \\
\text { \& Erman. } \\
(2017)\end{array}$ & $\begin{array}{l}\text { Subjek penelitian } \\
\text { adalah } 32 \text { peserta } \\
\text { didik SMP } \\
\text { Negeri } 1 \text { Kota } \\
\text { Mojokerto kelas } \\
\text { VII-F dan VII-G. }\end{array}$ & $\begin{array}{l}\text { - Jenis penelitian adalah } \\
\text { pre-experiment. } \\
\text { - Rancangan penelitian } \\
\text { menggunakan design } \\
\text { pre-test and post-test } \\
\text { design. }\end{array}$ & $\begin{array}{l}\text { - Hasil belajar di kelas VII- } \\
\text { F dan VII-G meningkat } \\
\text { baik dari aspek } \\
\text { pengetahuan maupun } \\
\text { keterampilan. }\end{array}$ \\
\hline $\begin{array}{l}\text { Fitriani, A., } \\
\text { Mulyaningrum, } \\
\text { E., R., \& } \\
\text { Rachmawati, } \\
\text { C., R. } \\
(2018)\end{array}$ & $\begin{array}{l}\text { Subjek penelitian } \\
\text { adalah peserta } \\
\text { didik kelas VIII } \\
\text { SMP Negeri } 11 \\
\text { Semarang. }\end{array}$ & $\begin{array}{l}\text { - Jenis penelitian adalah } \\
\text { quasi eksperimen non- } \\
\text { equivalent pretest- } \\
\text { posttest control group } \\
\text { design. } \\
\text { - Pengambilan sampel } \\
\text { menggunakan } \\
\text { purposive sampling. } \\
\text { - kelas VII-F sebagai } \\
\text { kelas eksperimen } 1 \text { dan } \\
\text { kelas VII-G eksperimen } \\
2 \text { (webbed). }\end{array}$ & $\begin{array}{l}\text { - Komparasi hasil belajar } \\
\text { kognitif Peserta didik } \\
\text { pada materi sistem } \\
\text { pernapasan manusia, } \\
\text { memiliki presentase } \\
\text { dengan kriteria sangat } \\
\text { baik dibandingkan } \\
\text { connected yang memiliki } \\
\text { presentase dengan } \\
\text { kriteria baik. }\end{array}$ \\
\hline $\begin{array}{l}\text { Setiawan, E., } \\
\text { Hidayati, H., \& } \\
\text { Dwiridal, L. } \\
\text { (2020) }\end{array}$ & $\begin{array}{l}\text { Subjek penelitian } \\
\text { adalah peserta } \\
\text { didik kelas VII-B } \\
\text { dan VII-C tahun } \\
\text { ajaran 2017/ } 2018 \\
\text { di } \\
\text { SMP N 1 } \\
\text { Bukittinggi }\end{array}$ & $\begin{array}{l}\text { - Jenis penelitian adalah } \\
\text { quasi Eksperimental. } \\
\text { - Rancangan penelitian } \\
\text { adalah Randomized } \\
\text { Control Only Design. } \\
\text { - Metode penelitian } \\
\text { menggunakan analisis } \\
\text { deskriptif kuantitatif. }\end{array}$ & 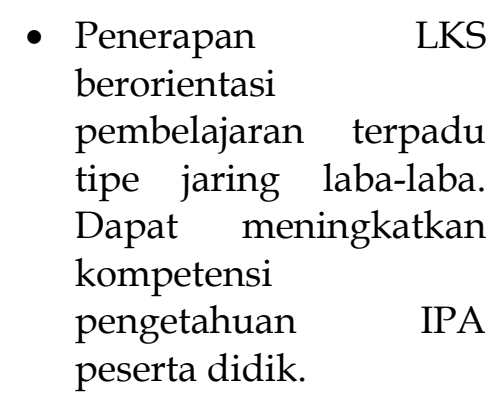 \\
\hline
\end{tabular}


Profil Implementasi Model Pembelajaran webbed dalam Mata Pelajaran IPA Terpadu di Indonesia (20132021)

\begin{tabular}{|c|c|c|c|}
\hline $\begin{array}{l}\text { Risma, M., } \\
\text { Khai, N., \& } \\
\text { Nafsih, N., Z } \\
\text { (2020) }\end{array}$ & $\begin{array}{l}\text { Subjek penelitian } \\
\text { adalah artikel } \\
\text { berjumlah 13, } \\
\text { yaitu } 11 \text { artikel } \\
\text { dari jurnal } \\
\text { nasional dan } 2 \\
\text { artikel dari jurnal } \\
\text { internasional. }\end{array}$ & $\begin{array}{l}\text { - Jenis penelitian adalah } \\
\text { meta analisis. } \\
\text { - Data pada penelitian } \\
\text { ini merupakan data } \\
\text { sekunder. }\end{array}$ & $\begin{array}{l}\text { - Model IPA terpadu tipe } \\
\text { webbed lebih efektif } \\
\text { diterapkan pada jenjang } \\
\text { pendidikan SMP pada } \\
\text { materi kalor. } \\
\text { - Dapat meningkatkan } \\
\text { keterampilan proses } \\
\text { sains. }\end{array}$ \\
\hline $\begin{array}{l}\text { Ramadhani, D., } \\
\text { P., Rini, A., \& } \\
\text { Asrizal. } \\
(2021)\end{array}$ & $\begin{array}{l}\text { Subjek penelitian } \\
\text { adalah artikel } \\
\text { berjumlah 25, } \\
\text { yaitu dari jurnal } \\
\text { nasional dan } \\
\text { jurnal } \\
\text { internasional . }\end{array}$ & $\begin{array}{l}\text { - Jenis penelitian adalah } \\
\text { meta analisis. } \\
\text { - Data pada penelitian } \\
\text { ini merupakan data } \\
\text { sekunder. }\end{array}$ & $\begin{array}{l}\text { - Meta analisis model } \\
\text { keterpaduan connected } \\
\text { effect size } 3,10 \text {, integrated } \\
2,18 \text {, dan webbed } 1,94 \text { dan } \\
\text { ketiga model } \\
\text { keterpaduan ini berada } \\
\text { pada kategori tinggi. }\end{array}$ \\
\hline
\end{tabular}

\section{Karakteristik Model Webbed}

IPA Terpadu adalah salah satu mata pelajaran tingkat SMP yang menggabungkan ilmu kimia, biologi dan fisika menjadi satu kesatuan. IPA Terpadu pada hakikatnya dikembangkan menjadi integrative science/IPA terintegrasi/IPA terpadu. Pembelajaran IPA terpadu memberikan kesempatan kepada siswa untuk mengembangkan kemampuan berpikir, keterampilan proses dan pengembangan sikap ilmiah. Sejumlah model pembelajaran terpadu menurut Fogarty (1991) tiga diantaranya sesuai untuk dikembangkan dalam pembelajaran IPA tingkat pendidikan di Indonesia. Ketiga model yang dimaksud adalah model keterhubungan (connected), model jaring laba-laba (webbed), dan model keterpaduan (integrated). Dalam pembelajaran IPA Terpadu model webbed memiliki karakteristik salah satunya yaitu dilakukan penentuan tema yang kemudian dikemangkan subtemanya dengan memperhatikan kaitannya dengan disiplin ilmu atau bidang studi lain. tema tersebut bisa saling terkait antara materi maupun pokok bahasan antar kelas, baik kelas yang lebih rendah, sederajat, maupun kelas yang lebih tinggi.

\section{Trend Penelitian}

Model webbed menjadi salah satu model pembelajaran terpadu yang dikembangkan di SMP. Berdasarkan penelitian yang dilakukan oleh Affin Nurul Hidayah, Yuni Sri Rahayu dan Beni Setiawan pada tahun 2013 bertujuan untuk menjelaskan kelayakan, keterlaksanaan pembelajaran, ketuntasan dan respon peserta didik terhadap perangkat pembelajaran IPA terpadu dapat diketahui bahwa perangkat pembelajaran yang dikembangkan sangat layak digunakan. Keterlaksanaan pembelajaran memperoleh kriteria sangat baik dan mendapatkan respon positif dari peserta didik dengan ketuntasan belajar peserta didik mencapai $86,67 \%$. Penerapan model pembelajaran IPA terpadu webbed sering dipadukan dengan beberapa tipe seperti integrated, connected, webbed, dan shared. Dalam penerapan

Sumber belajar adalah salah satu pendukung proses pembelajaran. Berdasarkan penelitian yang dilakukan oleh Khanif Syahidana Maulidy \& Winarsih (2013) mengembangkan bahan ajar pembelajaran IPA terpadu tipe webbed pada tema tanggap 
bencana layak digunakan dalam penelitian yang dilakukan bahan ajar pembelajaran IPA terpadu tipe webbed pada tema tanggap bencana layak digunakan dan mendapatkan respon peserta didik positif terhadap perangkat pembelajaran yang dikembangkan. Selain bahan ajar, perangkat pembelajaran juga merupakan salah satu komponen terpenting dalam pembelajaran. Berdasarkan penelitian yang dilakukan oleh Agus Santoso, Tarzan Purnomo, dan Ismono pada tahun 2013 di SMP Integral Luqman AlHakim Surabaya, dengan judul penelitian "Pengembangan Perangkat Pembelajaran IPA Terpadu Tipe Webbed pada Tema Pestisida untuk Melatihkan Karakter Siswa SMP". Dalam penelitian ini disebutkan bahwa respon peserta didik positif terhadap LKS, materi, buku siswa, media yang digunakan, cara guru mengajar dan suasana belajar. Selain itu, peserta didik mengalami perkembangan karakter menuju ke arah yang lebih baik yaitu karakter tanggung jawab, peduli lingkungan, peduli sosial dan kerja sama.

\section{Keunggulan Model Webbed}

Kelebihan model pembelajaran IPA terpadu model Webbed adalah: (1) penentuan tema atau materi pembelajaran dilakukan sesuai dengan minat peserta didik agar termotivasi untuk belajar, (2) model ini mudah dilakukan oleh tenaga pendidik yang belum berpengalaman mengajar, (3) perencanaan lebih mudah, (4) dapat memotivasi peserta didik, karena menggunakan pendekatan tematik, dan (5) Bagi peserta didik, dapat memberikan kemudahan karena dikaitkan dengan isu-isu yang saling terkait. Sedangkan kelemahannya: (1) Kecenderungan memilih materi atau tema pelajaran yang mudah dan (2) Guru terpusat pada proses pembelajaran, bukan terhadap pengembangan konsep. Keunggulan model Webbed adalah dapat memotivasi peserta didik dalam melihat keterkaitan pembelajaran dan gagasan tanpa melihat batas pemisah atara pembelajaran. Pada model pembelajaran IPA Terpadu model webbed, pembelajaran dimulai dari tema atau sub tema yang dipusatkan dari beberapa mata pelajaran.

\section{Kekurangan Model Webbed}

Meskipun banyak kelebihan, model webbed juga memiliki beberapa kekurangan diantaranya dibutuhkan waktu yang lebih dalam pembelajaran. Hal tersebut karena sebelum melakukan pembelajaran, terlebih dahulu ditentukan tema pembelajaran. Selain itu, kinerja guru dalam merancang sebuah pembelajaran juga diperlukan lebih ekstra. Berdasarkan hal tersebut dapat diketahui bahwasanya dalam menerapkan pembelajaran terpadu model webbed, guru memegang peranan yang sangat penting.

\section{Saran Penerapan Model Webbed}

Adapun saran yang dapat diberikan berdasarkan trend penelitian model webbed sebaiknya penggunaan pengalokasian waktu dengan baik sehingga tujuan pembelajaran tercapai dengan bisa terlaksana, selain itu guru diharapkan tidak monoton dalam menyampaikan materi pelajaran.

\section{KESIMPULAN}

Berdasarkan kajian literatur implementasi model pembelajaran IPA Terpadu tipe webbed pada tahun 2012-2021 yang telah dilakukan, dapat disimpulkan bahwa model pembelajaran IPA Terpadu tipe webbed berdampak berdampak positif dalam pelaksanaan pembelajaran formal dan pengembangan perangkat model pembelajaran IPA Terpadu tipe webbed sangat layak digunakan dengan mencapai aspek kevalidan, 
Profil Implementasi Model Pembelajaran webbed dalam Mata Pelajaran IPA Terpadu di Indonesia (20132021)

kepraktisan dan keefektifan. Penerapan pembelajaran IPA Terpadu tipe webbed dapat meningkatan hasil belajar peserta didik, meningkatkan ketuntasan belajar peserta didik baik klasikal maupun individual yang ditinjau dari aspek kognitif, afektif dan psikomotor. Selain itu implementasi model pembelajaran IPA Terpadu tipe webbed juga mendapatkan respon positif dari peserta didik.

\section{DAFTAR PUSTAKA}

Af'idah, A., R., Erman, \& Budiyanto, M. (2013). Penerapan Model Pembelajaran Berdasarkan Masalah pada Pembelajaran IPA Terpadu Tema Korosi Besi untuk Siswa Kelas VII Smp Negeri 1 Bungah Gresik. Jurnal Pendidikan Sains e-Pensa, 1(1), 66-70.

Ahmadi, N., Purnomo, T., \& Martini. (2013). Pengembangan Perangkat Pembelajarn Ipa Terpadu Tipe webbed pada Tema Pencemaran Air Berorientasi Model Problem Based Instruction (PBI) untuk Meningkatkan Hasil Belajar Siswa Kelas VII SMP. Jurnal Pendidikan Sains e-Pensa, 1(3), 1-5.

Aini, N., Tukiran, \& Qosyim, A. (2013). Model Penemuan Terbimbing (Guided Discovery) pada Pembelajaran Ipa Terpadu Tipe Webbed dengan Tema Biopestisida. Jurnal Pendidikan Sains e-Pensa, 1(2), 118-122.

Amarila, R., S., Habibah, N., A., \& Widiyatmoko, A. (2014). Pengembangan Alat Evaluasi Kemampuan Berpikir Kritis Siswa pada Pembelajaran Ipa Terpadu Model Webbed Tema Lingkungan. Unnes Science Education Journal, 3 (2), 563-569.

Baharun, H., \& Astriani, S., A., dkk. (2019). Pendekatan Webbed Learning pada Pembelajaran Tematik Terhadap Peserta Didik Inklusif di Madrasah. Journal of Education, 2 (1), 79-103.

Bahri, M., S., Sumaryanto, T., F., \& Haryono. 2020. Development of Nested-Integrated Learning Model in Indonesian Subject Based on 21 ${ }^{\text {st }}$ Century Learning. Journal of Curriculum and Educational Technology. 9(1), 10-16.

Bariroh, S., L, Muchlis \& Fauziah, N., M. (2014). Pengembangan Lembar Kerja Siswa (Lks) IPA Terpadu Berbasis Pembelajaran Berdasarkan Masalah Tema Polusi Cahaya Kelas VIII MTs Negeri Ngronggot Nganjuk . Jurnal Pendidikan Sains e-Pensa, 2(1), 123-128.

Choiriyah, F., Madlazim., \& Haryono, T. 2017. Pengembangan Perangkat Pembelajaran Model Nested Berbasis Inkuiri Terbimbing untuk Meningkatkan Pemahaman Konsep, Thinking skill dan social skill pada Siswa SMP. Jurnal Pendidikan Sains Pascasarjana Universitas Negeri Surabaya, 7(1), 1379-1385.

Fitriani, A., Mulyaningrum, E., R., \& Rachmawati, C., R. (2018). Komparasi Pembelajaran IPA Terpadu Tipe Connected dan Webbed melalui LSLC terhadap Hasil Belajar Kognitif Siswa di SMP Negeri 11 Semarang. Jurnal Biologi dan Pembelajarannya, 5(2). Habibah., N., K., \& Maryanto, A. 2019. The Influence of Nested type of Integrated Science Learning Model on Studentd Critical Thinking and Cooperation Skills. Journal of Science Education Research, 3(2), 33-39.

Heru \& Mulyaningsih., S. (2014). Penerapan Pembelajaran IPA Terpadu Tipe Webbed Menggunakan Model Pembelajaran Kooperatif STAD pada Tema Roket Air di Kelas VIII SMP Negeri 1 Dlanggu Mojokerto. Jurnal Pendidikan Sains e-Pensa, 2(1), 135-142. 
Profil Implementasi Model Pembelajaran webbed dalam Mata Pelajaran IPA Terpadu di Indonesia (20132021)

Hidayah, A., N., Rahayu, Y., S., \& Setiawan, B. (2013). Pengembangan Perangkat Pembelajaran IPA Terpadu Pola Webbed Berorientasi Keterampilan Proses Sains pada Tema 4P (Pengawet, Pewarna, Pemanis, Penyedap) dan Kesehatan untuk SMP Kelas VIII. Jurnal Pendidikan Sains e-Pensa, 1(2), 147-154.

Hilmawati, N., \& Hidayat, M., T. (2013). Pengembangan Perangkat Pembelajarn Ipa Terpadu Tipe webbed Berbasis Contextual Teaching And Learning pada Tema Pencemaran Air Kelas VII SMP. Jurnal Pendidikan Sains e-Pensa, 1(1), 89-94.

Kartika, F., \& Azizah, U. (2013). Pengembangan Perangkat Pembelajaran IPA Terpadu Tipe Webbed Tema Bioteknologi Bahan Pangan dalam Pembuatan Roti di SMPN 2 Pungging. Jurnal Pendidikan Sains e-Pensa, 1(2), 205-212.

Kuntasari, S. \& Masruri, M., S. 2016. Pengaruh Model Nested dan Webbed Terhadap Hasil Belajar IPS Terpadu SMP. Jurnal Ilmu-Ilmu Sosial, 15(1), 107-119.

Jubaidah, S., T., Mantasiah, R., Jufri \& Yusri. 2017. Keefektifan Model Pembelajaran Jaring Laba-Laba (Webbed) dalam Keterampilan Menulis Karangan Sederhana Bahasa Jerman. Jurnal Penelitian Pendidikan INSANI, 2(2), 89-95.

Lutviyah, I., \& Mulyaningsih, S. (2013). Penerapan Pembelajaran IPA Terpadu Tipe Webbed dengan Tema "Makanan Sehat" untuk Meningkatkan Hasil Belajar Siswa. Jurnal Pendidikan Sains e-Pensa, 1(2), 213-219.

Maulidy, S., K., \& Winarsih. (2013). Penerapan lembar kerja siswa (LKS) IPA Terpadu Tipe Webbed dengan Tema Pencemaran Air pada Siswa Kelas VII SMP Negeri 1 Labang Bangkalan. Jurnal Pendidikan Sains e-Pensa, 1(3), 107-112.

Mansurotun, S., Astriani, D., \& Sanjaya, I., G., M. (2014). Pengembangan Perangkat Pembelajaran IPA Terpadu Tipe Webbed Berorientasi Inkuiri Terbimbing Tema Rainbow Cake untuk Siswa SMP/MTS Kelas VIII. Jurnal Pendidikan Sains e-Pensa, 2(1), 111-116.

Margaretta, Y., \& Erman. (2017). Penerapan Lembar Kegiatan Siswa (Lks) IPA Tipe Webbed untuk Meningkatkan Hasil Belajar Siswa pada Tema Limbah Rumah Tangga Kelas VII. Jurnal Pendidikan Sains e-Pensa, 5(3), 195-199.

Martono, N. 2010. Metode Penelitian Kuantitatif : Analisis Isi dan Analisis Data Sekunder. Depok : PT. Rajagrafindo Persada.

Meri, N., Y, ddk,. (2016). Penerapan Model Pembelajaran Brain Based Learning Menggunakan Pembelajaran IPA Terpadu Tipe Webbed dan Connected pada Materi Pemanasan Global untuk Meningkatkan Penguasaan Konsep dan Kps. Jurnal Edusains, 8 (2), 128-135.

Mirzaqon, A., T. \& Purwoko, B. 2018. Studi Kepustakaan Mengenai Landasan Teori dan Praktik Konseling Expressive Writing. Jurnal BK Unesa, 8(1).

Mulyatiningsih, E. 2014. Metode Penelitian Terapan Bidang Pendidikan. Bandung : CV Alfabeta.

Nabila, A., Supartono., \& Nurhayati., S. 2017. Keefektifan Model Pembelajaran Nested dengan Pendekatan Kontekstual pada Hasil Belajar Siswa. Jurnal Unnes (Chemistry in Education), 6(1), 1-7.

Nazila, M., R., A., \& Suliyanah. (2013). Penerapan Pembelajaran Langsung pada Ipa Terpadu Tipe Webbed dengan Tema Makanan dan Kesehatan di Kelas VII SMP Negeri 2 Jombang. Jurnal Pendidikan Sains e-Pensa, 1(1), 8-12. 
Profil Implementasi Model Pembelajaran webbed dalam Mata Pelajaran IPA Terpadu di Indonesia (20132021)

Ningsih, N., W ., dkk. (2013). Pengembangan Perangkat Pembelajaran Ipa Terpadu Tipe Webbed Tema Tercemarkah Airku di Kelas VII Smp. Jurnal Pendidikan Sains e-Pensa, $1(1), 54-59$.

Nuraida, A., M., Widiantle., R., \& Setiawati, I. 2019. Implementasi Pembelajaran Terpadu Nested dengan Mengintegrasikan Topik Sistem Eksresi dan Keterampilan Proses Sains. Jurnal Pendidikan dan Biologi. 11(1), 43-48.

Priscylio, G., \& Anwar, S. (2019). Integrasi Bahan Ajar IPA Menggunakan Model Robin Forgaty Untuk Proses Pembelajaran IPA di SMP. Jurnal Pinar Mipa, 14(1),1-12.

Putri, K., E., Ismono, \& Rosdiana, L. (2013). Pengembangan Perangkat Pembelajaran Ipa Terpadu Tipe Webbed dengan Tema Pemanasan Global untuk Kelas VIII. Jurnal Pendidikan Sains e-Pensa, 1(2), 42-46.

Rachmadani, D., \& Supardi, Z., A., I. (2013). Penembangan Perangkat Pembelajaran Ipa Terpadu Tipe Webbed dengan Tema Tekanan Darah untuk SMP Kelas VIII. Jurnal Pendidikan Sains e-Pensa, 1(1), 104-110.

Rahmatika, R., Ismono, \& Budiyanto, M. (2013). Perangkat Pembelajaran Ipa Terpadu Tipe Webbed pada Tema Pengolahan Minyak Kelapa untuk Siswa SMP Kelas VII. Jurnal Pendidikan Sains e-Pensa, 1(2), 30-34.

Ramadhani, D., P., Rini, A., \& Asrizal. 2021. Meta Analisis Pengaruh Modul IPA Terpadu Terhadap Hasil Belajar Siswa SMP. Jurnal Penelitian dan Pembelajaran Fisika, 7(1), 2634.

Ridho, S., Haryani, S., \& Habibah, N., A. (2014). Pengembangan Modul Ipa Terpadu Model Webbed pada Tema Hama dan Pestisida. Unnes Science Education Journal, 3 (3), 609-615.

Risma, M., Khai, N., \& Nafsih, N., Z. 2020 . Meta Analisis: Pengaruh Model Keterpaduan Tipe Webbed Terhadap Pengetahuan dan Keterampilan IPA Peserta DidiK. Jurnal Penelitian dan Pembelajaran Fisika, 6(1).

Sapari, H., Jatmiko, B., \& Hidayat, T.,2015. Pengembangan Perangkat Pembelajaran IPA Terpadu Model Nested untuk Meningkatkan Pemahaman Konsep, Keterampilan Mengorganisir dan Keterampilan Berpikir pada Materi Kalor. Jurnal Pendidikan Sains Pascasarjana Universitas Negeri Surabaya, 5(1), 753-763.

Sari, D., P., Mitarlis., \& Rosdiana, L. (2013). Penerapan Pembelajaran Ipa Terpadu Tipe Webbed dengan Model Pembelajaran Berdasarkan Masalah Tema Hujan Asam pada Siswa SMP Negeri 1 Manyar Gersik. Jurnal Pendidikan Sains e-Pensa, 1(3), 6067.

Sari, F., I., \& Mulyaningsih, S. (2013). Penerapan Perangkat Pembelajaran Ipa Terpadu Tipe Webbed Melalui Model Pembelajaran Kooperatif STAD Pada Materi “Tsunami" di Kelas VII SMP Negeri 19 Surabaya. Jurnal Pendidikan Sains e-Pensa, 1(3), 145-149. Santoso, A., Purnomo, T., \& Ismono. (2013). Penembangan Perangkat Pembelajaran Ipa Terpadu Tipe Webbed pada Tema Peptisida untuk Melatihkan Karakter Siswa SMP. Jurnal Pendidikan Sains e-Pensa, 1(1), 60-66.

Setiawan, E., Hidayati, H., \& Dwiridal, L. (2020). Pengaruh penerapan LKS berorientasi pembelajaran terpadu tipe jaring laba-laba terhadap kompetensi IPA siswa kelas VII SMPN 1 Bukittinggi. Pillar Of Physich Education, 6(1).

Sukarsih, L. (2017). Development of Integrated Natural Science Teaching Materials Webbed Type with Applying Discourse Analysis on Students Grade VIII in Physics Class. Jurnal Of Physics : Conference Series, 1(3), 107-112. 
Suryaneza, H., \& Permanasari, A. (2016). Penerapan Pembelajaran IPA Terpadu Menggunakan Model webbed untuk Meningkatkan Literasi Sains Siswa. E-Joernal UIN Jakarta, 1(3), 36-47.

Syamsudin, Ibrahim, M., \& Widodo, W. (2016). Pengembangan Perangkat Pembelajaran IPA Terpadu Tipe Webbed Berbasis Inkuiri Terbimbing untuk Melatih Kemnadirian Belajar dan Kecakapan Hidup Siswa SMP. Jurnal Pendidikan Sains Pascasarjana Universitas Negeri Surabaya , 6(1).

Tanjung, R., \& Kamal, R. (2013). Pengaruh Pembelajaran Terpadu Model Webbed Terhadap Hasil Belajar Siswa pada Sub Materi Pokok Hukum Pascal di Kelas VIII Semester II SMP Swasta Ikal Medan T.P.2011/2012. Jurnal INPAFI, 1(1).

Utami, K., C., Darsana, I., W \& Suadyana, I., N. 2014. Pengaruh Model Pembelajaran Cooperative Integrated Reading Composition Terhadap Hasil Belajar IPA Siswa Kelas V. Jurnal Mimbar PGSD Universitas Pendidikan Ganesha, 2(1).

Yulianingrum, \& Rahayu, y., S. (2013). Penerapan Pembelajaran Ipa Terpadu Tipe Webbed Berorientasi Kecakapan Hidup (Life Skill) Pada Tema Suara Kelas VIII SMP ALAMAL Surabaya. Jurnal Pendidikan Sains e-Pensa, 1(1), 1-7.

Zakiyah, I., Mulyaningsih, S., \& Setiawan B. (2013). Penerapan Pembelajaran Ipa Terpadu Tipe Webbed pada Tema Kebakaran Hutan untuk Meningkatkan Keterampilan Berpikir Kritis Siswa. Jurnal Pendidikan Sains e-Pensa, 1(2), 66-71.

Zuraida, I., Kariadinata, R., \& Susilawati, W. (2015). Mind Map Siklus dan Mind Map Laba-Laba untuk Meningkatkan Kemampuan Berpikir Kreatif Siswa SMP pada Pokok Bahasan Bangun Ruang. Jurnal Pengajaran MIPA, 20(1), 11-17.

\footnotetext{
* Irda Sukmawati Dewi (Corresponding Author)

Universitas Negeri Surabaya,

Jl. Ketintang, Ketintang, Kec. Gayungan, Kota Surabaya, Jawa Timur 60231, Indonesia

Email: irda.18083@mhs.unesa.ac.id
} 